\title{
Do Plants Have a Choice of Traits to Be Modulated? Evidence from an Invasive Plant Mikania micrantha Kunth in Different Urban Environments
}

\author{
Achyut Kumar Banerjee1, Swayambhu Ghosh1,2, Anjana Dewanji1 ${ }^{*}$ \\ ${ }^{1}$ Agricultural and Ecological Research Unit, Indian Statistical Institute, Kolkata, India \\ ${ }^{2}$ Soils Department, Tocklai Tea Research Institute, Assam, India \\ Email: *anjdew@gmail.com
}

How to cite this paper: Banerjee, A.K., Ghosh, S. and Dewanji, A. (2017) Do Plants Have a Choice of Traits to Be Modulated? Evidence from an Invasive Plant Mikania micrantha Kunth in Different Urban Environments. American Journal of Plant Sciences, 8, 835-855.

https://doi.org/10.4236/ajps.2017.84057

Received: February 2, 2017

Accepted: March 26, 2017

Published: March 30, 2017

Copyright (c) 2017 by authors and Scientific Research Publishing Inc. This work is licensed under the Creative Commons Attribution International License (CC BY 4.0).

http://creativecommons.org/licenses/by/4.0/

\begin{abstract}
The successful establishment of an invasive plant in a novel environment has been attributed to the phenotypic plasticity of plant traits, with most studies focussing on vegetative trait plasticity in either experimental and/or natural habitat conditions. This study explores the role of phenotypic plasticity, in both vegetative and reproductive traits, of an invasive plant Mikania micrantha growing as a ground cover in diverse urban areas in the city of Kolkata, India. Quadrat based plant and soil sampling was conducted in three habitat types, namely roadsides, natural areas and abandoned plots, from four regions within the city. The above ground biomass and fitness related vegetative and seed traits were estimated from the plant samples whereas soil macro-and micro-nutrients as well as soil health (in terms of organic carbon and microbial biomass carbon) were estimated from the soil samples. Habitat-specific selection of traits in $M$. micrantha was observed in this study. In roadside population which has more chances of long distance dispersal, the excessive production of reproductive biomass as a compensatory response to the low germination ability of the seeds was evident. In natural areas which are more prone to anthropogenic disturbance and where the plant has greater chances of local spread, modulation of both vegetative (higher SLA) and reproductive traits (lighter seeds with faster germination ability) helped the plant to maintain its population. In abandoned plots where there was more number of associated species, the longer span of germination and increased population height ensured the survivability of $M$. micrantha in the community. Thus, a continuous monitoring program to check for $M$. micrantha growth should be prioritized in urban areas due to its immense trait plasticity in different habitat conditions where uncontrolled growth can lead to its establishment and spread, thereby making its control more difficult.
\end{abstract}




\section{Keywords}

Phenotypic Plasticity, Traits, Urbanization, Invasive Plant, Germination

\section{Introduction}

Mikania micrantha Kunth, commonly known as "mile-a-minute" weed, is considered to be one of the top 10 worst weeds of the world [1]. This herbaceous creeper with a pantropical distribution has now spread to Oceania and most of the Asian countries [2]. Its detrimental presence in India has been reported mainly from forests and plantations of southwest and northeast India [3] [4]. Since the past few years, luxuriant growth of $M$. micrantha has also been noted along roadsides, abandoned plots, managed plantations, and on the margins of water bodies in the metropolitan city of Kolkata, although these were mostly restricted to small ground cover patches [5]. Urban areas often act as immigration gateways for invasive species to enter through transportation networks [6] where they initially reside in small isolated patches leading to their lower visibility and lesser chance of detection. These small patches then become propagule sources for spread to natural areas [7] [8] thereby increasing their chance of successful establishment in a novel environment [9]. After establishment, invasive plants can alter the soil profile through their direct and indirect effects [10]. Native species often fail to cope up with the altered soil conditions in disturbed urban environments, thereby paving the way for successful colonization of non-native species.

Studies on phenotypic plasticity, or the ability of the same genotype to express different phenotypes in response to different environmental conditions [11], provide key ecological understanding of the underlying mechanisms of an invasive plant's success in a novel environment [12] [13]. Modulation of phenotypic plastic traits provide invasive species a competitive advantage over the native species in the community by overcoming a series of biotic and abiotic barriers for successful establishment, broadening its habitat niche in the invaded range [14] [15], and enabling it to grow and reproduce in a wide range of environmental conditions [14] [16] [17] [18]. Being plastic may allow a population of invaders (even one as small as 10 - 20 individuals) to quickly adapt to the new environment and to maintain higher fitness relative to the native taxa, thereby establishing dominance in the community [14].

Leaf traits are widely studied since they are the key functional traits that are linked to plant responses to environmental variability [19] [20] [21] and stress tolerance [22]. The majority of these studies focus on differences between species, using species average trait values (e.g. [23] [24] [25]). However, plant functional traits can vary substantially within species [26] [27] and therefore taking intraspecific trait variation into account may improve the accuracy and resolution of such studies [28]. The importance of reproductive traits such as the germination behaviour of a species has recently been highlighted to be a critical 
factor for a species to become invasive in novel environments [29] [30]. A short-term germination advantage provides invasive species with a strong competitive advantage over native species [31] which can strongly affect the fitness, growth and survival of a species in a community [30] [32].

There are a few studies that have explored trait modulation strategies for individual plants growing in an urban environment in the Indian sub-continent (e.g., Ricinus communis [33], Calotropis procera [34]). Precise locally collected data available from different regions and environments [35], especially for the most serious invaders, would aid in obtaining meaningful results. Most world-wide trait based experimental studies on $M$. micrantha have primarily focused on its vegetative traits. The species has been reported to have higher photosynthetic activity, greater water and photosynthetic nitrogen use efficiency [36], low leaf construction cost [37], and high regeneration capacity from clonal fragments [38] to explain its competitive advantage in the community by using comparisons of congeners. However, much less is known about the plasticity of the sexual reproductive traits of $M$. micrantha as well as its adaptive potential in a heterogeneous urban environment. Along with its year-long vegetative growth, M. micrantha also reproduces sexually during the winter season [39]. In spite of producing self-incompatible flowers, $M$. micrantha has been found to be an extremely successful colonizer [40], and appears to be an exception to the Baker's law [41]. The plasticity in mating systems has been found to increase the long-distance colonizing ability of an invasive species, and assuring reproduction at low population densities [42] which could be crucial for invaders to colonize urban areas. In view of increasing urbanization, which is now considered a major driving force of plant biodiversity loss and community homogenization [43], integrated studies involving both vegetative and reproductive traits that affect the ability of a population to tolerate environmental heterogeneity [44], are necessary for understanding the plasticity patterns in M. micrantha.

This study was, therefore, formulated to evaluate the importance of phenotypic plasticity in vegetative and reproductive traits involved in $M$. micrantha's tolerance to different habitat conditions in an urban environment. A basic understanding of the soil characteristics on growth of $M$. micrantha in different disturbance prone areas could also help undermine the difference in trait plasticity responsible for their fast adaptability in urban areas. The hypothesis to be tested was that the survival ability of M. micrantha is a function of plasticity of its fitness-related traits (in terms of both growth and reproduction) to heterogeneous habitat conditions induced by anthropogenic disturbances prevalent within an urban locality.

\section{Materials and Methods}

\subsection{Site Description and Sampling Design}

The Greater Kolkata region $\left(88^{\circ} 22^{\prime} 15.66^{\prime \prime} \mathrm{E}, 22^{\circ} 39^{\prime} 20.48^{\prime \prime N}\right)$, with a wide mosaic of contrasting habitats, was chosen as the study area (Figure 1(a)). The area was divided into four regions (north, south, east, west) within which three habitats 
from each region were selected with profuse $M$. micrantha growth, considered to be representative of the disturbance factors prevalent in an urban locality. The three habitat types were roadsides (Figure 1(b)) with vehicular disturbance, natural areas (Figure 1(c)) with maximum anthropogenic disturbance, and abandoned plots (Figure 1(d)) with minimal disturbance. Some of the factors which influence disturbance regimes in roadsides, natural area and abandoned plots have been listed in Table 1 .

The study was conducted during the winter season (January to February, 2015) with temperatures ranging from $13^{\circ} \mathrm{C}-16^{\circ} \mathrm{C}$ with no or negligible precipitation. In this season, $M$. micrantha reproduces sexually by forming seeds along with its year-long vegetative growth. This season ensured availability of both vegetative as well as sexual reproductive traits, presumably involved in local adaptation and closely related to fitness. In each habitat type, a quadrat based sampling method [45] was chosen for recording and collecting plant and soil samples from three representative sites. The above ground biomass and individual samples for plant traits were collected from two different quadrats, each of size $0.5 \times 0.5$ sq. m. (Figure 1(b1), Figure 1(c1), Figure 1(d1)). A smaller quadrat of size $0.25 \times 0.25$ sq. $\mathrm{m}$ was used to sample and estimate the seed related traits (Figure 1(b2), Figure 1(c2), Figure 1(d2)). After harvesting the above ground biomass, soil samples were collected from within the same quadrat (Figure 1(b3), Figure 1(c3), Figure 1(d3)).

At each site, prior to plant sample collection, the community composition within the quadrat $(0.5 \times 0.5$ sq. $\mathrm{m})$ was also recorded. The associated plants occurring with $M$. micrantha were identified and recorded while some of the unknown species were sampled and identified later from the Botanical Survey of India (BSI), Shibpur, Howrah.

\subsection{Estimation of Plant above Ground Biomass and Traits}

Ten randomly selected 8-noded individual plants were sampled from the first quadrat of size $0.5 \times 0.5$ sq. $\mathrm{m}$ for measurement of leaf related traits and ten other plants were additionally harvested for measurement of proline content. Since it is otherwise not possible to select plants of uniform age due to its vegetative mode of reproduction, the $8^{\text {th }}$ nodal leaf from the tip of each plant was selected to overcome any age-related variation. The average height of the plant population was estimated from 10 random observations recorded within the second quadrat $(0.5 \times 0.5$ sq. $\mathrm{m})$ following which the total above ground biomass (a measure chosen for quantifying the productivity of the sites) was harvested.

All individual plants and biomass samples were brought to the laboratory in polythene bags. Proline was estimated from fresh plant samples following Bates et al. [46], and expressed on a fresh weight basis. The leaf related trait measurements along with laminar nitrogen, phosphorus, and potassium content were estimated following standard protocols (Table 2), and expressed on a leaf area basis. The vegetative and reproductive biomass was measured separately and expressed on a dry weight basis along with the nitrogen content of the plant parts. 


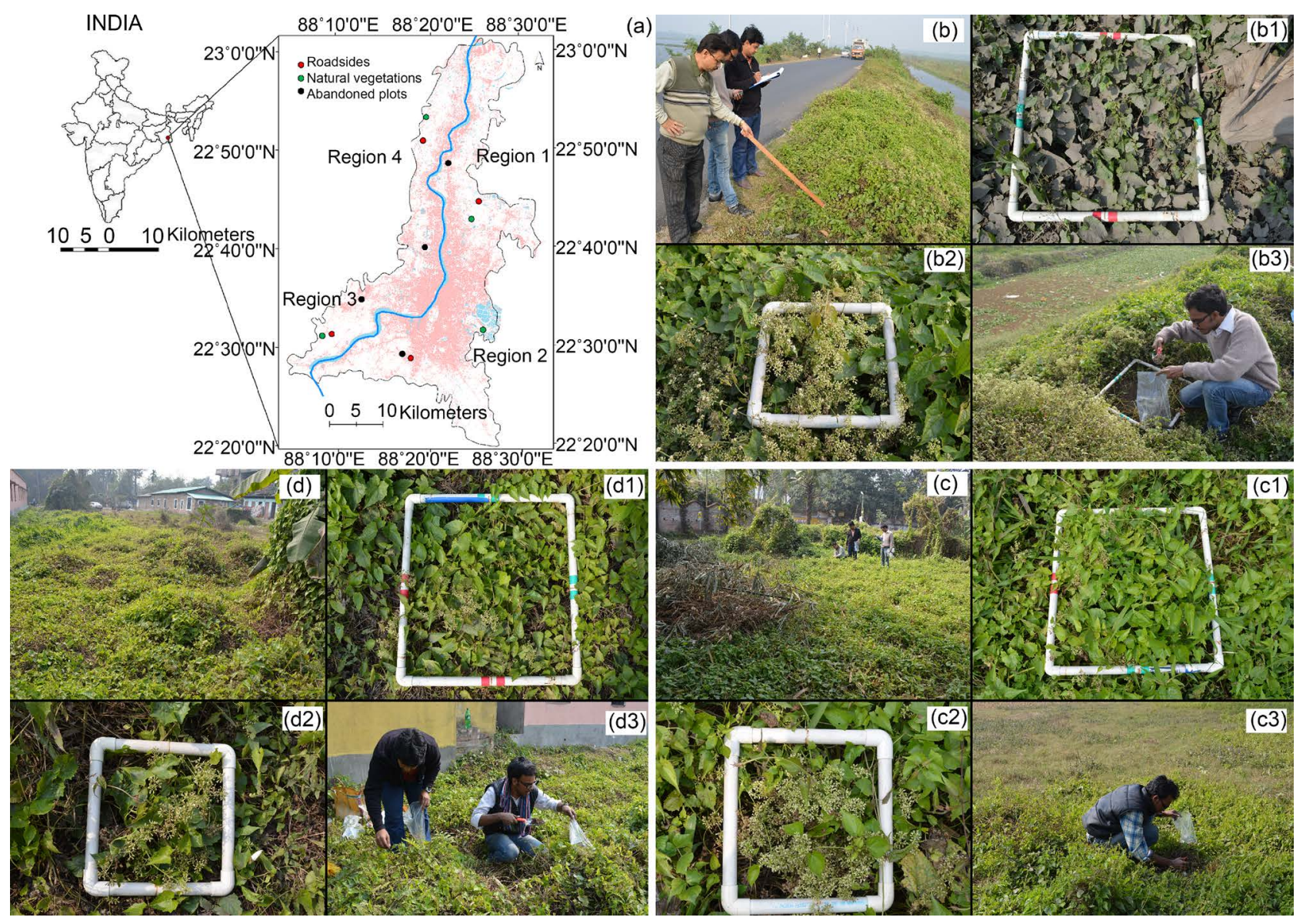

Figure 1. Site characteristics of the three habitats with M. micrantha growth. (a) Location of the three habitats in the four regions of the Greater Kolkata area; (b) M. micrantha patch along roadsides, (b1) $0.5 \times 0.5$ sq. m. sampling of above ground biomass, note the dust deposition on the leaves, (b2) seed sampling from within a $0.25 \times 0.25$ sq. m. quadrat, (b3) soil sampling; (c) M. micrantha patch in a natural habitat, (c1) above ground biomass sampling from within a $0.5 \times 0.5 \mathrm{sq}$. m. quadrat, (c2) seed sampling, (c3) soil sampling; (d) M. micrantha patch in an abandoned plot, (d1) $0.5 \times 0.5$ sq. m. sampling of the above ground biomass, (d2) seed sampling, (d3) soil sampling.

Table 1. Disturbance characteristics prevalent in the three habitats within the study area.

\begin{tabular}{|c|c|c|c|}
\hline \multirow{2}{*}{$\begin{array}{l}\text { Disturbance } \\
\text { characteristics }\end{array}$} & \multicolumn{3}{|c|}{ Habitat types } \\
\hline & $\begin{array}{c}\text { Roadsides } \\
(\mathrm{n}=12)\end{array}$ & $\begin{array}{l}\text { Natural areas } \\
\quad(\mathrm{n}=12)\end{array}$ & $\begin{array}{l}\text { Abandoned plots } \\
(\mathrm{n}=12)\end{array}$ \\
\hline \multicolumn{4}{|l|}{ Vehicular } \\
\hline Dust deposition & Yes & No & No \\
\hline Automobile waste & Yes & No & No \\
\hline \multicolumn{4}{|l|}{ Anthropogenic } \\
\hline Road construction material & Yes & No & No \\
\hline Construction debris & No & Yes & No \\
\hline Plastic wastes & No & Yes & Yes \\
\hline Human trampling & No & Yes & No \\
\hline Bio-excreta & No & Yes & Yes \\
\hline
\end{tabular}


Table 2. Details of vegetative and reproductive traits of $M$. micrantha studied in the three urban habitat types.

\begin{tabular}{|c|c|c|c|}
\hline & Plant traits & $\begin{array}{c}\text { Units of } \\
\text { measurement }\end{array}$ & Methods of measurement \\
\hline \multirow{6}{*}{ 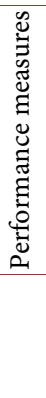 } & Above Ground biomass & gm & $\begin{array}{l}\text { Destructive sampling of plant materials within a quadrat of } 0.5 \times 0.5 \mathrm{sq} \text {. } \\
\mathrm{m} \text {. size }\end{array}$ \\
\hline & \multicolumn{3}{|c|}{ The above ground biomass was divided into vegetative and reproductive plant parts } \\
\hline & Vegetative biomass & gm & Includes stems and leaves of plant samples \\
\hline & Reproductive biomass & gm & Includes the inflorescence of plants \\
\hline & Population height & $\mathrm{cm}$ & $\begin{array}{l}\text { Average height of the population measured on } 10 \text { mature individuals } \\
\text { up to the general height of the foliage }\end{array}$ \\
\hline & Average species richness & Number & Number of associated species within the quadrat \\
\hline \multirow{10}{*}{ 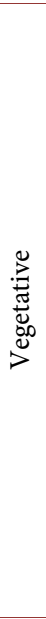 } & Leaf surface area (LA) & $\mathrm{mm}^{2}$ & $\begin{array}{l}\text { Scanned measurements of } 2 \text { fresh } 8^{\text {th }} \text { nodal leaves of each of } 10 \text { indi- } \\
\text { vidual plants using a flat-bed scanner providing. tiff images which were } \\
\text { processed using the software LAFORE [48] }\end{array}$ \\
\hline & \multicolumn{3}{|c|}{ The pooled estimate of a sample of 10 individuals' aggregate LA was used to calculate the leaf traits } \\
\hline & Lamina dry biomass & gm & $\begin{array}{l}\text { Lamina samples }(2 \times 10 \text { plants }) \text { oven-dried to constant weight at } 75^{\circ} \mathrm{C} \\
\text { for } 3 \text { days }\end{array}$ \\
\hline & Specific Leaf Area (SLA) & $\mathrm{mm}^{2} \cdot \mathrm{g}^{-1}$ & LA divided by its oven-dry mass \\
\hline & Leaf Dry Matter Content (LDMC) & $\mathrm{mg} \cdot \mathrm{g}^{-1}$ & Calculated as dry weight divided by fresh weight of lamina \\
\hline & Proline & $\mathrm{n} \cdot \mathrm{mol} \cdot \mathrm{g}^{-1} \cdot \mathrm{FW}$ & Following standard methodology of Bates et al. [46] \\
\hline & Vegetative $\mathrm{N}$ & $\% \mathrm{~N} \cdot \mathrm{mg}^{-1}$ & $\begin{array}{l}\text { Vegetative N per mg of plant sample following Nelson and Sommers } \\
\text { [49] }\end{array}$ \\
\hline & Laminar $\mathrm{N}$ area $^{-1}$ & $\% \mathrm{~N} \cdot \mathrm{mm}^{-2}$ & Lamina N/lamina area \\
\hline & Laminar $\mathrm{P}$ area ${ }^{-1}$ & $\mathrm{mg} \cdot \mathrm{kg}^{-1} \cdot \mathrm{mm}^{-2}$ & Lamina P (estimated colorimetrically following [50])/Lamina area \\
\hline & Laminar $\mathrm{K}$ area $^{-1}$ & $\mathrm{mg} \mathrm{kg}^{-1} \cdot \mathrm{mm}^{-2}$ & Lamina $\mathrm{K}$ (estimated in flame photometer following [51])/Lamina area \\
\hline \multirow{5}{*}{ 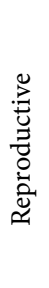 } & Reproductive N & $\% \mathrm{~N} \cdot \mathrm{mg}^{-1}$ & Reproductive N per mg of plant sample [49] \\
\hline & Seed weight & gm & \multirow{4}{*}{$\begin{array}{l}\text { Following standard methodology of estimation of seed germination } \\
\text { parameters [47] }\end{array}$} \\
\hline & $\begin{array}{l}\text { Final Germination } \\
\text { Percentage }\end{array}$ & $\%$ & \\
\hline & Mean Germination Time (MGT) & Days & \\
\hline & Median Germination Time (T50) & Days & \\
\hline
\end{tabular}

\subsection{Estimation of Seed Traits}

Mature capitulums were harvested from within a $0.25 \times 0.25$ sq. m. quadrat (Figure 1(b2), Figure 1(c2), Figure 1(d2)). The seeds were removed from the mature capitulum and 100 seed weight estimated for each site. For germination studies, 50 seeds per site, with 3 replicates each, were set in petri dishes and maintained in a controlled environment of a Growth Chamber (Temperature- $27^{\circ} \mathrm{C}$, Humidity-75\%, $16 \mathrm{~h}$ light $8 \mathrm{~h}$ dark). The seeds were considered as germinated with the onset of 2 leaves. The germinated seeds were counted daily and removed from the Petri dish to avoid the repeat counting error. The experiment lasted for one month, and the following germination parameters were estimated following standard methodologies [47]:

Final Germination percentage (FGP) $=$

(Number of germinated seeds/Total number of planted seeds) $\times 100$

Mean germination time $(\mathrm{MGT})=\left(\sum D_{n}\right) /\left(\sum n\right)$ 
where, $n=$ number of seeds germinated on day $D$, and

$D=$ number of days counted from the beginning of the germination.

Germination Index $(G I)=\left(\sum G_{t}\right) / D_{t}$

where, $G_{t}$ is the number of germinants at day $t$ and

$D_{t}$ is the number of days that have elapsed.

Median germination time $(\mathrm{T} 50)=$

Time taken for $50 \%$ of the seeds to germinate.

All the above parameters involve only those seeds that were able to germinate in the allotted time essentially regarded as Restricted MGTs and T50s [52]. These severely underestimate the true MGT and T50 of the seed lot because they do not adjust for the larger germination times which remain unobserved due to termination of the experiment. Thus, it is also necessary to consider viable seeds that have not germinated/emerged at the end of an experiment (also known as censored observations). These censored observations were also taken into account to estimate the germination survival functions [53].

\subsection{Soil Sampling and Estimation of Soil Parameters}

After harvesting the above ground plant biomass, soil samples from each site were collected from a depth of $0-10 \mathrm{~cm}$ from a $0.5 \times 0.5 \mathrm{sq}$. m. quadrat by using soil-grab-sampling method (Figure 1(b3), Figure 1(c3), Figure 1(d3)). The soil samples were divided into two fractions, put in polythene bags and brought to the laboratory. One fraction of soil was air-dried and sieved using a $2 \mathrm{~mm}$ sieve to remove plant materials, soil micro fauna, debris and stones. The air-dried samples were analyzed for available nitrogen $(\mathrm{N})$ following the Kjeldahl method [54], available phosphorus ( $\mathrm{P}$ ) following colorimetric molybdenum-blue-method [55], available potassium $(\mathrm{K})$ following neutral ammonium acetate extract method determined by flame photometer [56] and organic carbon (OC) using $\mathrm{K}_{2} \mathrm{Cr}_{2} \mathrm{O}_{7}-\mathrm{H}_{2} \mathrm{SO}_{4}$ oxidation method following Nelson and Sommers [57]. The concentrations of heavy metals like copper, zinc, iron and manganese, all of which are considered to be essential micronutrients for plants, were also estimated following standard methods of Lindsay and Norwell [58]. Major sources of these metals in urban soils include vehicular emission and industrial waste materials [59].

The remaining fraction of the fresh soil sample (3 replications for each site) was analysed to estimate microbial biomass carbon $\left(\mathrm{C}_{\text {mic }}\right)$, a biological and eco-physiological indicator of soil quality for sustaining plant growth [60], using the chloroform fumigation-extraction method [61]. In this method, each sample was divided into two sub-samples (10 $\mathrm{g}$ dry weight equivalent) of which one was fumigated with ethanol free chloroform for $24 \mathrm{~h}$ in a vacuum desiccator, while the other was treated as a control. Both the fumigated as well as the control samples were extracted with $0.5 \mathrm{M} \mathrm{K}_{2} \mathrm{SO}_{4}$ for 30 minutes ( $300 \mathrm{rpm}$ ) in an oscillator [62] and the resulting extracts filtered. $\mathrm{C}_{\text {mic }}$ in filtrates was determined by potassium dichromate method and computed using the difference between fumigated and control samples with a conversion factor of 0.38 for $\mathrm{C}_{\text {mic }}$ [61]. $\mathrm{C}_{\text {mic }}$ values 
were finally expressed as soil microbial quotient $\mathrm{C}_{\text {mic }} / \mathrm{C}_{\text {org }}$ (the ratio of the microbial biomass $\mathrm{C}$ to organic $\mathrm{C}$ ) following Li et al. [63].

\subsection{Statistical Analysis}

All data were checked for their compliance with assumptions of normality and non-normal data subjected to various transformations based on their frequency distribution. For normally distributed data, comparison of plant (vegetative and reproductive) and soil traits among different habitats was done using one-way ANOVA followed by post-hoc Tukey's HSD test, whereas non-parametric alternatives of between groups' comparison tests, namely Kruskal-Wallis $\mathrm{H}$ and post-hoc Mann-Whitney U test, were applied to the data that was not normally distributed. For comparing plant and soil parameters between the three habitats, there were 12 ( 3 sites $\times 4$ regions) observations for each habitat. For all cases, the significance level was set at $5 \%$ level of probability.

To estimate germination survival functions, the 'germination time' was used to calculate the germination probability, i.e. the probability that an individual seed germinates after a specific time ' $t$ ', considering the initial event at $t=0$. The germination probability was estimated non-parametrically by using the Kaplan-Meier method for every seed lot (i.e. seeds sampled from the population of roadsides, natural areas, and abandoned plots) including the censored observations. The null hypothesis i.e. no difference in the overall germination probability between groups (i.e. different habitats) was tested using the Log-rank (Mantel-Cox) test [64] [65] which calculates a Chi-square $\left(\chi^{2}\right)$ statistic that is compared to a $\chi^{2}$-distribution with two degrees of freedom. The survival plot displays the time course of germination probabilities (or the germination functions) which takes the form of a non-increasing step function, starting from 1 at time 0 and approaching 0 as time increases [53].

All the statistical analyses were carried out using SPSS version 18.0 and R version 3.2 while data and outputs were visualized by SigmaPlot Version 12.0.

\section{Results}

\subsection{Vegetative Traits of M. micrantha}

There was no significant difference in the productivity of $M$. micrantha populations, as is evident from the total above ground biomass values for the three habitats in Table 3 . However, the roadside population produced significantly higher amount of reproductive biomass (mean biomass $=9.9 \mathrm{gm} \pm 2.6)$ in comparison to natural areas $(1.2 \mathrm{gm} \pm 0.5 ; \mathrm{p}=0.002)$ and abandoned plots $(1.5 \mathrm{gm} \pm$ $0.5 ; \mathrm{p}=0.008)$.

The vegetative and reproductive trait values of $M$. micrantha in the three habitat types are also presented in Table 3. The roadside plants were found to produce significantly higher LA $\left(29.37 .3 \mathrm{~mm}^{2} \pm 524.6 ; \mathrm{p}=0.047\right)$ and have higher LDMC values $\left(0.18 \mathrm{mg} \cdot \mathrm{g}^{-1} \pm 0.01 ; \mathrm{p}=0.008\right)$ in comparison to the plants of natural areas. The proline content was found to be significantly high in plants of natural areas $\left(19.2 \mathrm{n} \cdot \mathrm{mol} \cdot \mathrm{g}^{-1} \pm 4.4 ; \mathrm{p}=0.001\right)$ and roadside populations 
Table 3. Vegetative and reproductive traits of $M$. micrantha in the three urban habitat types.

\begin{tabular}{|c|c|c|c|c|}
\hline \multirow[b]{2}{*}{ Plant traits } & \multirow[b]{2}{*}{$\begin{array}{l}\text { Units of } \\
\text { measurement }\end{array}$} & \multicolumn{3}{|c|}{ Habitats } \\
\hline & & $\begin{array}{l}\text { Roadsides } \\
(\mathrm{n}=12)\end{array}$ & $\begin{array}{l}\text { Natural areas } \\
\quad(\mathrm{n}=12)\end{array}$ & $\begin{array}{c}\text { Abandoned } \\
\text { plots } \\
(\mathrm{n}=12)\end{array}$ \\
\hline \multicolumn{5}{|l|}{ Biomass } \\
\hline Above Ground biomass & gm & $44.8 \pm 3.1$ & $36.0 \pm 4.2$ & $35.4 \pm 3.6$ \\
\hline Vegetative biomass & gm & $34.9 \pm 2.9$ & $34.8 \pm 4.3$ & $33.9 \pm 3.5$ \\
\hline Reproductive biomass & gm & $9.9^{a} \pm 2.6$ & $1.2^{\mathrm{b}} \pm 0.5$ & $1.5^{\mathrm{b}} \pm 0.5$ \\
\hline \multicolumn{5}{|l|}{ Community level } \\
\hline Population height & $\mathrm{cm}$ & $5.1 \pm 0.5$ & $4.5 \pm 0.1$ & $6.2 \pm 0.8$ \\
\hline Average species richness & Number & $2.08 \pm 0.3$ & $2.83 \pm 0.2$ & $5.25 \pm 0.4$ \\
\hline \multicolumn{5}{|l|}{ Vegetative traits } \\
\hline Leaf surface Area (LA) & $\mathrm{mm}^{2}$ & $\begin{array}{l}2937.3^{\mathrm{a}} \pm \\
524.6\end{array}$ & $\begin{array}{c}1701.1^{\mathrm{b}} \pm \\
184.4\end{array}$ & $\begin{array}{c}2033.7^{\mathrm{ab}} \pm \\
250.9\end{array}$ \\
\hline Specific Leaf Area (SLA) & $\mathrm{mm}^{2} \cdot \mathrm{g}^{-1}$ & $\begin{array}{c}12362.2 \pm \\
1838.9\end{array}$ & $\begin{array}{c}14854.9 \pm \\
1510.5\end{array}$ & $\begin{array}{c}11753.3 \pm \\
1140.2\end{array}$ \\
\hline $\begin{array}{l}\text { Leaf Dry Matter Content } \\
\text { (LDMC) }\end{array}$ & $\mathrm{mg} \cdot \mathrm{g}^{-1}$ & $0.18^{\mathrm{a}} \pm 0.01$ & $0.15^{\mathrm{b}} \pm 0.01$ & $0.17^{\mathrm{ab}} \pm 0.01$ \\
\hline Proline & $\mathrm{n} \cdot \mathrm{mol} \cdot \mathrm{g}^{-1} \cdot \mathrm{FW}$ & $12.2^{\mathrm{a}} \pm 2.1$ & $19.2^{\mathrm{a}} \pm 4.4$ & $5.4^{\mathrm{b}} \pm 1.2$ \\
\hline Vegetative $\mathrm{N}$ & $\% \mathrm{~N} \cdot \mathrm{mg}^{-1}$ & $1.96 \pm 0.2$ & $1.99 \pm 0.3$ & $1.76 \pm 0.2$ \\
\hline Laminar $\mathrm{N}$ area $^{-1}$ & $\% \mathrm{~N} \cdot \mathrm{mm}^{-2}$ & $0.19 \pm 0.03$ & $0.26 \pm 0.03$ & $0.24 \pm 0.04$ \\
\hline Laminar $\mathrm{P}$ area ${ }^{-1}$ & $\mathrm{mg} \cdot \mathrm{kg}^{-1} \cdot \mathrm{mm}^{-2}$ & $0.03 \pm 0.01$ & $0.04 \pm 0.01$ & $0.03 \pm 0.01$ \\
\hline Laminar $\mathrm{K} \operatorname{area}^{-1}$ & $\mathrm{mg} \cdot \mathrm{kg}^{-1} \cdot \mathrm{mm}^{-2}$ & $25.1^{\mathrm{a}} \pm 4.5$ & $90.9^{\mathrm{b}} \pm 12.8$ & $41.1^{\mathrm{a}} \pm 8.6$ \\
\hline \multicolumn{5}{|l|}{ Reproductive traits } \\
\hline Reproductive N & $\% \mathrm{~N} \cdot \mathrm{mg}^{-1}$ & $2.2^{\mathrm{a}} \pm 0.2$ & $2.1^{\mathrm{ab}} \pm 0.2$ & $1.6^{\mathrm{b}} \pm 0.03$ \\
\hline Seed weight & gm & $\begin{array}{l}0.0077 \pm \\
0.001\end{array}$ & $\begin{array}{c}0.0059 \pm \\
0.0002\end{array}$ & $\begin{array}{c}0.0086 \pm \\
0.0012\end{array}$ \\
\hline $\begin{array}{l}\text { Final Germination } \\
\text { Percentage }\end{array}$ & $\%$ & $71.8 \pm 3.5$ & $82.2 \pm 4.2$ & $81.0 \pm 3.2$ \\
\hline $\begin{array}{l}\text { Mean Germination Time } \\
\text { (MGT) }\end{array}$ & Days & $5.1^{\mathrm{a}} \pm 0.5$ & $4.5^{\mathrm{a}} \pm 0.1$ & $6.2^{\mathrm{b}} \pm 0.8$ \\
\hline $\begin{array}{l}\text { Median Germination } \\
\text { Time (T50) }\end{array}$ & Days & $5.0 \pm 0.22$ & 4.0 & $5.0 \pm 0.18$ \\
\hline
\end{tabular}

Different lower case letters indicate significant differences between the seasons, as revealed by Tukey's HSD test and Mann-Whitney test at $\mathrm{p}=0.05$ level.

$\left(12.2 \mathrm{n} \cdot \mathrm{mol} \cdot \mathrm{g}^{-1} \pm 2.1 ; \mathrm{p}=0.005\right)$ than those in abandoned plots $\left(5.4 \mathrm{n} \cdot \mathrm{mol} \cdot \mathrm{g}^{-1} \pm\right.$ 1.2). The plants in the natural areas showed maximum SLA $\left(14854.9 \mathrm{~mm}^{2} \cdot \mathrm{g}^{-1}\right)$ in comparison to the other two habitats. The abandoned plots had the maximum number of associated species $(5.25 \pm 0.4)$ and $M$. micrantha was found to attain maximum height $(6.2 \mathrm{~cm} \pm 0.8)$ in this habitat.

\subsection{Reproductive Traits of M. micrantha}

Significantly high amount of reproductive $\mathrm{N}\left(2.2 \% \mathrm{~N} \cdot \mathrm{mg}^{-1} \pm 0.2\right)$ was found in 
the roadside population of $M$. micrantha when compared to that of abandoned plots $\left(1.6 \% \mathrm{~N} \cdot \mathrm{mg}^{-1} \pm 0.03 ; \mathrm{p}=0.011\right)$. However, the final germination percentage of the seeds from the roadside population was found to be the lowest $(71.8 \%$ \pm 3.5 ) among the three habitat types. The lightest seeds of M. micrantha population in natural habitats $(0.0059 \mathrm{gm} \pm 0.0002)$ showed fastest germination capability in terms of having the lowest MGT and T50 values (Table 3). In the abandoned plots, $M$. micrantha population produced heavier seeds $(0.0086 \mathrm{gm} \pm$ 0.0012 ) and took a significantly longer time to germinate (MGT $=6.2$ days \pm 0.8$)$ compared to those from roadside population (5.1 days $\pm 0.5 ; \mathrm{p}=0.038)$ and natural areas ( 4.5 days $\pm 0.1 ; \mathrm{p}=0.009)$.

\subsection{Seed Survival Functions of M. micrantha}

The analysis of seed germination survival functions using the log-rank test, presented in the Kaplan-Meier survival plots (Figure 2), revealed a significant difference in germination survival functions between the seeds of the three different habitats $\left(\chi^{2}=35.1 ; \mathrm{p}<0.001\right)$. The seeds of $M$. micrantha from natural areas showed significantly better germination survival function than the seeds from roadside population $\left(\chi^{2}=29.3 ; \mathrm{p}<0.001\right)$ and those from abandoned plots $\left(\chi^{2}=\right.$ 18.4; $\mathrm{p}<0.001$ ). As evident from the survival plots (Figure 2 ), the seeds sampled from the abandoned plots (represented by blue line) required more number of days for the germination process to be completed (as evident from more number of step functions) in comparison to that of the seeds sampled from roadsides as well as natural areas.

The probability of having censored seeds (not having germinated) after 7 days

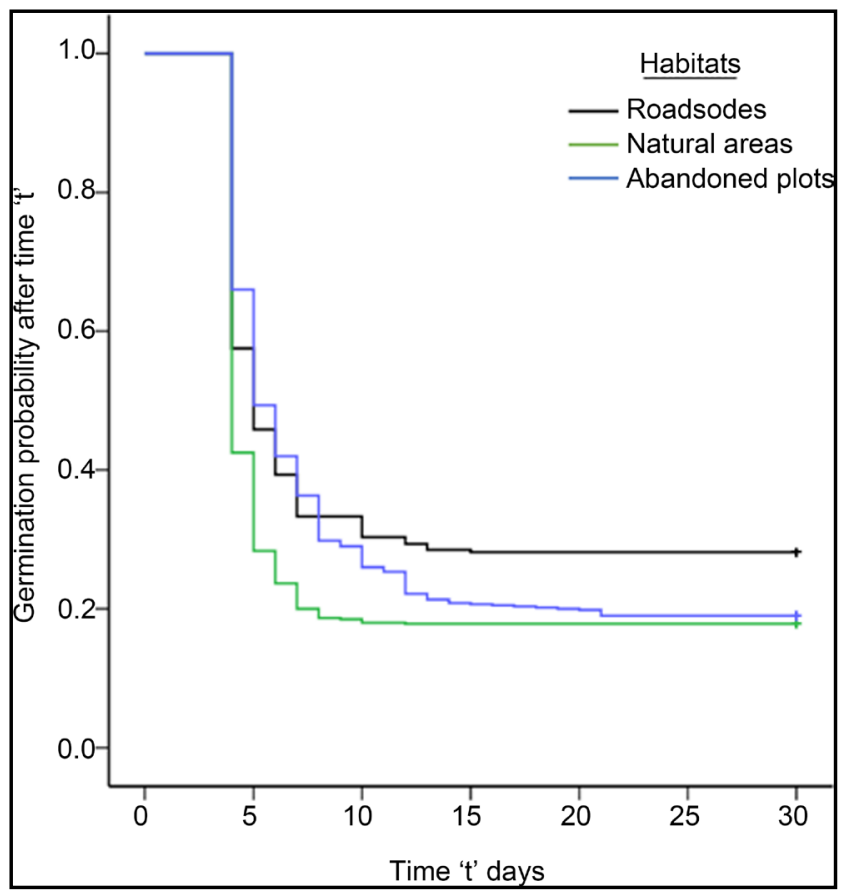

Figure 2. Kaplan-Meier survival plots of $M$. micrantha seeds sampled from three different habitats. The final cross represents censored observations. 
$(t=7)$ was maximum in abandoned plots $[P(7)=0.36 \pm 0.02]$, followed by those in roadsides $[P(7)=0.33 \pm 0.02]$ and natural habitats $[P(7)=0.2 \pm 0.016]$ (Table 4). It took 12 days for the germination process to be completed in seeds sampled from $M$. micrantha population growing in natural habitats with the lowest probability of having the censored seeds $[\mathrm{P}(12)=0.178 \pm 0.016]$ compared to 15 days in those from roadside population $[\mathrm{P}(15)=0.282 \pm 0.018]$ and 21 days in those from abandoned plots [P $(21)=0.19 \pm 0.016]$.

\subsection{Analysis of Soil Parameters in the Three Habitat Types}

Soil nitrogen content was found to be significantly low along roadsides $(0.0109 \%$ $\pm 0.0012)$ in comparison to natural areas $(0.0207 \% \pm 0.0026 ; \mathrm{p}=0.008)$ and abandoned plots $(0.0239 \% \pm 0.0019 ; \mathrm{p}<0.001)$ (Table 5$)$. The OC content was the lowest in roadside soils, though not significant. MBC values $(501.4 \mu \mathrm{g} / \mathrm{gm} \pm$ 61.6) were significantly lower along roadsides when compared to natural areas $(1101.6 \mu \mathrm{g} / \mathrm{gm} \pm 120.6 ; \mathrm{p}<0.001)$ and abandoned plots $(1267.6 \mu \mathrm{g} / \mathrm{gm} \pm 226.5 ; \mathrm{p}$ $=0.005)$. Among the heavy metals, manganese $(\mathrm{Mn})$ content was significantly

Table 4. Estimated probability of having censored seeds at time $t$ (varying from 4 to 21 days) for the seed lots sampled from the three different habitats of the study area.

\begin{tabular}{|c|c|c|c|}
\hline \multicolumn{4}{|c|}{ Probability of having censored seeds } \\
\hline \multirow{2}{*}{ At time (t days) } & \multicolumn{3}{|c|}{ In habitats } \\
\hline & Roadsides & Natural areas & Abandoned plots \\
\hline 04 & $0.580 \pm 0.020$ & $0.430 \pm 0.020$ & $0.660 \pm 0.019$ \\
\hline 05 & $0.460 \pm 0.020$ & $0.280 \pm 0.020$ & $0.493 \pm 0.020$ \\
\hline 06 & $0.390 \pm 0.020$ & $0.240 \pm 0.020$ & $0.420 \pm 0.020$ \\
\hline 07 & $0.330 \pm 0.020$ & $0.200 \pm 0.016$ & $0.363 \pm 0.020$ \\
\hline 08 & - & $0.187 \pm 0.016$ & $0.298 \pm 0.019$ \\
\hline 09 & - & $0.185 \pm 0.016$ & $0.290 \pm 0.019$ \\
\hline 10 & $0.303 \pm 0.019$ & $0.180 \pm 0.016$ & $0.260 \pm 0.018$ \\
\hline 11 & - & - & $0.253 \pm 0.018$ \\
\hline 12 & $0.293 \pm 0.019$ & $0.178 \pm 0.016$ & $0.222 \pm 0.017$ \\
\hline 13 & $0.285 \pm 0.018$ & - & $0.213 \pm 0.017$ \\
\hline 14 & - & - & $0.208 \pm 0.017$ \\
\hline 15 & $0.282 \pm 0.018$ & - & $0.207 \pm 0.017$ \\
\hline 16 & - & - & $0.205 \pm 0.016$ \\
\hline 17 & - & - & $0.203 \pm 0.016$ \\
\hline 18 & - & - & $0.202 \pm 0.016$ \\
\hline 19 & - & - & $0.200 \pm 0.016$ \\
\hline 20 & - & - & $0.198 \pm 0.016$ \\
\hline 21 & - & - & $0.190 \pm 0.016$ \\
\hline
\end{tabular}

“_" in a cell indicates no germination event recorded on that day, and thus the probability of having censored seeds remains unchanged from the previous day. 
Table 5. Estimates of soil parameters in the three habitats of the study area.

\begin{tabular}{lcccc}
\hline Soil parameters & $\begin{array}{c}\text { Units of } \\
\text { measurement }\end{array}$ & Roadsides & Natural areas & Abandoned plots \\
\hline Available N & $\%$ & $0.0109^{\mathrm{a}} \pm 0.0012$ & $0.0207^{\mathrm{b}} \pm 0.0026$ & $0.0239^{\mathrm{b}} \pm 0.0019$ \\
Available $\mathrm{P}$ & $\%$ & $0.0074^{\mathrm{a}} \pm 0.0004$ & $0.0052^{\mathrm{ab}} \pm 0.0011$ & $0.0038^{\mathrm{b}} \pm 0.0008$ \\
Available $\mathrm{K}$ & $\%$ & $0.0231 \pm 0.0024$ & $0.0646 \pm 0.0189$ & $0.0291 \pm 0.0033$ \\
Organic carbon & $\mu \mathrm{g} / \mathrm{gm}$ & $19423.1 \pm 1935.4$ & $24884.7 \pm 2663.7$ & $20156.5 \pm 2234.2$ \\
$\mathrm{MBC}$ & $\mu \mathrm{g} / \mathrm{gm}$ & $501.4^{\mathrm{a}} \pm 61.6$ & $1101.6^{\mathrm{b}} \pm 120.6$ & $1267.7^{\mathrm{b}} \pm 226.5$ \\
$\mathrm{C}_{\text {mic }} / \mathrm{C}_{\text {org }}$ & - & $2.7^{\mathrm{a}} \pm 0.3$ & $4.7^{\mathrm{a}^{\mathrm{b}}} \pm 0.5$ & $6.7^{\mathrm{b}} \pm 1.1$ \\
$\mathrm{Cu}$ & $\mathrm{ppm}$ & $12.6 \pm 3.7$ & $5.5 \pm 1.2$ & $10.9 \pm 3.8$ \\
$\mathrm{Zn}$ & $\mathrm{ppm}$ & $10.7 \pm 2.2$ & $7.3 \pm 2.0$ & $8.1 \pm 1.6$ \\
$\mathrm{Mn}$ & $\mathrm{ppm}$ & $27.1^{\mathrm{a}} \pm 4.3$ & $65.7^{\mathrm{b}} \pm 3.0$ & $63.8^{\mathrm{b}} \pm 4.0$ \\
$\mathrm{Fe}$ & $\mathrm{ppm}$ & $39.8 \pm 5.2$ & $53.0 \pm 10.7$ & $39.6 \pm 5.8$ \\
\hline
\end{tabular}

Different lower case letters indicate significant differences between the seasons, as revealed by Tukey's HSD test and Mann-Whitney $\mathrm{U}$ test at $\mathrm{p}=0.05$ level.

low in roadside soils $(27.1 \mathrm{ppm} \pm 4.3)$ as compared to natural areas $(65.7 \mathrm{ppm} \pm$ 3.0; $\mathrm{p}<0.001)$ and abandoned plots $(63.8 \mathrm{ppm} \pm 4.0 ; \mathrm{p}<0.001)$.

\section{Discussion}

The ability of the plant to grow in all the studied habitats of an urban locality was evident from the non-significant difference in the productivity of $\mathrm{M} . \mathrm{mi}$ crantha population (vegetative biomass) across the habitat types. However, a significant high amount of reproductive biomass of M. micrantha in the roadside population possibly indicated the ability of the plant to modulate its reproductive trait in response to disturbance prevalent along roadsides. Similar kinds of trait modulation in disturbance gradients of urban habitat have been reported in other plants, e.g. Ricinus communis [33] and Calotropis procera [34].

\subsection{Modulation of Plant Traits along Roadsides}

The soil along roadsides appeared to be resource poor compared to the other two habitats, as evident from a significantly low soil $\mathrm{N}, \mathrm{Mn}$ content and $\mathrm{MBC}$ values. While soil nitrogen is critical for plant growth [66], soil Mn is an essential micro-nutrient and is the key to the entire status of soil redox [67]. A potentially low redox is known to negatively affect soil microorganisms [68], which is probably reflected from the low MBC values in the roadside soils.

A high probability of germination failure in this habitat could have resulted from the low seed resource content as evident from its lighter seeds. However, the roadside $M$. micrantha population was found to produce a large number of seeds in order to ensure population sustainability. The roadside plants are often exposed to high vehicular disturbance which enables the seeds to be carried over long distances [69] [70]. To ensure survivability of seeds, the plants possibly al- 
located more resources to its reproductive part, as evident from the significantly high amount of reproductive $\mathrm{N}$ content. The capacity to produce a large number of seeds at the expense of vegetative structures is one of the key strategies of the invasive species to maintain a steady dynamic population [33].

This strategic adaptation of $M$. micrantha was also evident in the laminar characteristics of its roadside population through its high LDMC values, signifying high content of sclerenchyma and vascular tissues [71], and lower amount of laminar $\mathrm{N}$ content. More-over, large amount of dust deposition on the leaf surface of the roadside population could result in blockage of stomatal conductance [72] [73] which might decrease photosynthetic efficiency. To counteract this and to compensate for the preferential resource allocation to reproductive parts, the roadside plants were found to produce significantly large LA for better acquisition of sunlight and increased photosynthetic efficiency.

It is interesting to note that in this low resource environment $M$. micrantha, being a disturbance tolerant species [74], could exist in monocultures along the roadsides. A high uptake rate of mineral $\mathrm{N}$ by $M$. micrantha for its monospecific growth could also be responsible for the low soil $\mathrm{N}$ concentration observed along roadsides [36] [75]. Swamy and Ramakrishnan [76] reported high phosphorus concentration in shoots of $M$. micrantha which indicates its capacity to mobilize and store soil P. High levels of available $\mathrm{P}$ in $M$. micrantha invaded roadside plots could also influence its growth induced by a rapid phosphorus cycle [75].

The ground cover form of M. micrantha, as found in this study, is very likely to form a canopy over the resident species, causing their death and subsequent decay which could be another major strategy of $M$. micrantha to achieve dominance in the community [79]. Moreover, this life form could be directly detrimental to native vegetation since it covers the soil surface and could smother other low-growing plants by inhibiting native seedling regeneration [77]. The low number of average species richness accounts for the loss of other associated species in this habitat.

\subsection{Modulation of Plant Traits in Natural Areas}

A significantly high amount of proline in the leaves of $M$. micrantha could be indicative of the higher stress that the population in natural areas are exposed to compared to the other two habitats possibly due to the influence of more anthropogenic disturbance. Proline acts as a marker of stress and its accumulation may be part of a stress signal which might influence adaptive responses [78] in plants by modulating both its vegetative as well as reproductive traits. Among the vegetative traits, possession of high SLA allows efficient capture of solar energy which enables opportunistic resource acquisition for growth and reproduction in invasive plants. This appears to be a key mechanism that makes SLA so important for invasive species [79]. SLA is closely correlated with other plant traits such as photosynthetic capacity, leaf $\mathrm{N}$ content, leaf life-span, and importantly, relative growth rate [80]. In this non-limiting resource environment of natural areas with comparatively higher soil $\mathrm{N}$ values, high SLA reflected the 
expected return on assimilated resources [81], thereby maintaining the productivity of the population. The ability to produce leaves with an increased surface area rapidly and to avoid significant investment of biomass in long lasting structures is critical in disturbed natural habitats where fast growth is supreme.

Among the reproductive traits, the population produced light seeds with fast germination ability. The presence of low amount of storage food reserves in the seeds, as evident from its low seed weight, could have resulted in faster (low MGT and T50) and more efficient germination of seeds. This is also evident from the low probability of having censored seeds at the end of the germination experiment. A capacity for rapid germination is a useful strategy to mitigate the effects of inter-specific competition [82] [83], as it can suppress the germination or establishment of later germinating seedlings of neighboring species [84]. The seed germination efficiency has been considered as one of the key traits of plant invasiveness [30]. Increased disturbance enhances seed production [85] and copious production of light, wind-dispersed seeds is generally correlated with the ability to respond to large disturbances [86].

\subsection{Modulation of Plant Traits in Abandoned Plots}

The absence or minimal presence of disturbance in the abandoned plots was evident from a significantly low amount of proline in $M$. micrantha leaves, and the increased availability of soil nutrients, resulting in a higher species richness. In this habitat, with more number of resident species in the community, M. micrantha was found to increase its average population height to be able to harvest more light energy, and increase its photosynthetic efficiency. The height of a population has been recognized to be one of the key strategies for invasive plant success in a competitive environment [87].

Less disturbed abandoned plots facilitate soil microbes to utilize organic carbon more efficiently than in natural areas. Consequently, an increase in microbial biomass was observed in this habitat. A high microbial biomass in soils with low organic carbon probably resulted in a higher soil microbial quotient in abandoned plots when compared to those from natural areas. This quotient is an important index by which the ability of soil micro-organisms in the recycling of carbon, nitrogen, and phosphorus in soils can be assessed [88]. High values of the microbial quotient, as observed in this habitat, reflects the efficiency of microbial incorporation and stabilization of soil organic carbon by the soil mineral fractions [89]. It, therefore, indicates that the average availability of OC is greatly improved and turnover on soil carbon pool is enhanced. This increase of bioavailability of soil nutrients may be another factor for M. micrantha in becoming a successful invader [63]. A well-developed root system of $M$. micrantha also ensures a high nutrient competitive ability compared to other associated plants with lower root biomass [74], enabling it to grow rapidly, and to suppress other plants in the process.

M. micrantha population were found to have the highest seed weight, thereby implying more food reserves which might help in establishing its progenies in a 
community where a large number of species compete for space and resources. The high amount of storage material in the seeds enable seedlings to compete better with superior survivability [33], eventually leading to a significantly high MGT of the seeds. However, despite having the longest duration of germination process, as found in the survival analysis, the probability of having censored seeds is less than $20 \%$. This finding indicates the efficiency of the $M$. micrantha population to allocate resources in production of seeds with enough food storage to sustain the germination process in a competitive environment and to assure efficient germination as well.

\section{Conclusions}

This study, for the first time, demonstrates the phenotypic plasticity of $M . m i$ crantha traits (both vegetative and sexual reproductive traits) in a disturbed urban environment. The production of more reproductive biomass in the roadside population, modulation of both vegetative and reproductive traits in anthropogenically disturbed natural areas and increased population height with a longer span of seed germination in abandoned plots enabled the plant to maintain its population in the different habitat types.

Patch of M. micrantha was found close to road networks in Kolkata in our earlier study [5] which is indicative of its increasing chance of dispersal to uninvaded interior areas where the plant can successfully grow and establish its population. Moreover, the plant has also been observed to grow luxuriantly along the margins of the waterbodies [90]. With its highly adaptive ability, the plant is therefore capable of increasing its range from conventional terrestrial to littoral habitats also, thereby escalating the problem many folds. Given the fact that $M$. micrantha is difficult to control once it attains dominance in the community, a continuous monitoring, irrespective of habitat types, should be prioritized to detect and timely respond to a rapid increase in its population.

\section{Acknowledgements}

The authors would like to thank Indian Statistical Institute for necessary funding of this research. The authors are thankful to the Botanical Survey of India for their assistance in identification of the plant species and Soil, Water and Manure Testing Laboratory of Vivekananda Institute of Biotechnology, Nimpith, West Bengal (India) for their assistance in analysis of soil parameters. The authors are grateful to Prof. Anup Dewanji of Applied Statistics Unit for statistical advice, and Mrs. Arpita Ganguly, Mr. Sandip Chatterjee and Mr. Susant Mahankur (AERU, ISI) for their technical and field assistance. We would like to thank the anonymous reviewers for their helpful suggestions.

\section{References}

[1] Holm, L.G., Plucknett, D.L., Pancho, J.V. and Herberger, J.P. (1977) The World's Worst Weeds. University Press, Jadavpur.

[2] Day, M. (2012) Mikania Micrantha Kunth-Mile-a-Minute. In: Julien, M., McFa- 
dyen, R. and Cullen, J., Eds., Biological Control of Weeds in Australia, CSIRO, Canberra, 368-372.

[3] Sankaran, K. and Sreenivasan, M. (1999) Status of Mikania Infestation in the Western Ghats. In: Sankaran, K.V., Murphy, S.T., Evans, H.C., Anitha, V. and Sreenivasan, M.A., Eds., Alien Weeds in Moist Tropical Zones: Banes and Benefits, Kerala Forest Research Institute, Peechi, 67-76.

[4] Puzari, K., Bhuyan, R., Dutta, P. and Nath, H. (2010) Distribution of Mikania and Its Economic Impact on Tea Ecosystem of Assam. Indian Journal of Forestry, 33, 71-76.

[5] Banerjee, A.K., Reddy, C.S. and Dewanji, A. (2016) Impact Assessment on Floral Composition and Spread Potential of Mikania Micrantha Hbk in an Urban Scenario. Proceedings of the National Academy of Sciences, India Section B: Biological Sciences, 1-12.

[6] McKinney, M.L. (2006) Urbanization as a Major Cause of Biotic Homogenization. Biological Conservation, 127, 247-260. https://doi.org/10.1016/j.biocon.2005.09.005

[7] Von der Lippe, M. and Kowarik, I. (2008) Do Cities Export Biodiversity? Traffic as Dispersal Vector across Urban-Rural Gradients. Diversity and Distributions, 14, 18 25. https://doi.org/10.1111/j.1472-4642.2007.00401.x

[8] Wittig, R. (2004) The Origin and Development of the Urban Flora of Central Europe. Urban Ecosystems, 7, 323-329. https://doi.org/10.1007/s11252-005-6833-9

[9] Lockwood, J.L., Cassey, P. and Blackburn, T. (2005) The Role of Propagule Pressure in Explaining Species Invasions. Trends in Ecology \& Evolution, 20, 223-228. https://doi.org/10.1016/j.tree.2005.02.004

[10] Weidenhamer, J.D. and Callaway, R.M. (2010) Direct and Indirect Effects of Invasive Plants on Soil Chemistry and Ecosystem Function. Journal of Chemical Ecology, 36, 59-69. https://doi.org/10.1007/s10886-009-9735-0

[11] Pigliucci, M. (2001) Phenotypic Plasticity: Beyond Nature and Nurture. The Johns Hopkins University Press London.

[12] Davidson, A.M., Jennions, M. and Nicotra, A.B. (2011) Do Invasive Species Show Higher Phenotypic Plasticity Than Native Species and, If So, Is It Adaptive? A Meta-Analysis. Ecology Letters, 14, 419-431. https://doi.org/10.1111/j.1461-0248.2011.01596.x

[13] Valladares, F., Gianoli, E. and Gómez, J.M. (2007) Ecological Limits to Plant Phenotypic Plasticity. New Phytologist, 176, 749-763. https://doi.org/10.1111/j.1469-8137.2007.02275.x

[14] Sultan, S.E. (2001) Phenotypic Plasticity for Fitness Components in Polygonum Species of Contrasting Ecological Breadth. Ecology, 82, 328-343. https://doi.org/10.1890/0012-9658(2001)082[0328:PPFFCI]2.0.CO;2

[15] Roughgarden, J. (1972) Evolution of Niche Width. The American Naturalist, 106, 683-718. https://doi.org/10.1086/282807

[16] Pyšek, P. and Richardson, D.M. (2008) Traits Associated with Invasiveness in Alien Plants: Where Do We Stand? In: Nentwig, W., Ed., Biological Invasions, Springer-Verlag, Berlin, 97-125.

[17] Van Kleunen, M., Weber, E. and Fischer, M. (2010) A Meta-Analysis of Trait Differences between Invasive and Non-Invasive Plant Species. Ecology Letters, 13, 235 245. https://doi.org/10.1111/j.1461-0248.2009.01418.x

[18] Hejda, M., Pyšek, P. and Jarošík, V. (2009) Impact of Invasive Plants on the Species Richness, Diversity and Composition of Invaded Communities. Journal of Ecology, 97, 393-403. https://doi.org/10.1111/j.1365-2745.2009.01480.x 
[19] Garnier, E., Laurent, G., Bellmann, A., Debain, S., Berthelier, P., Ducout, B., Roumet, C. and Navas, M.L. (2001) Consistency of Species Ranking Based on Functional Leaf Traits. New Phytologist, 152, 69-83. https://doi.org/10.1046/j.0028-646x.2001.00239.x

[20] Leishman, M.R., Haslehurst, T., Ares, A. and Baruch, Z. (2007) Leaf Trait Relationships of Native and Invasive Plants: Community- and Global-Scale Comparisons. New Phytologist, 176, 635-643. https://doi.org/10.1111/j.1469-8137.2007.02189.x

[21] Wang, G., Liu, J. and Meng, T. (2015) Leaf Trait Variation Captures Climate Differences but Differs with Species Irrespective of Functional Group. Journal of Plant Ecology, 8, 61-69. https://doi.org/10.1093/jpe/rtu009

[22] Westoby, M., Falster, D.S., Moles, A.T., Vesk, P.A. and Wright, I.J. (2002) Plant Ecological Strategies: Some Leading Dimensions of Variation between Species. Annual Review of Ecology and Systematics, 33, 125-159. https://doi.org/10.1146/annurev.ecolsys.33.010802.150452

[23] Ackerly, D.D. and Cornwell, W. (2007) A Trait-Based Approach to Community Assembly: Partitioning of Species Trait Values into within-and among-Community Components. Ecology Letters, 10, 135-145. https://doi.org/10.1111/j.1461-0248.2006.01006.x

[24] Duru, M., Ansquer, P., Jouany, C., Theau, J. and Cruz, P. (2010) Comparison of Methods for Assessing the Impact of Different Disturbances and Nutrient Conditions Upon Functional Characteristics of Grassland Communities. Annals of Botany, 106, 823-831. https://doi.org/10.1093/aob/mcq178

[25] Amatangelo, K.L., Johnson, S.E., Rogers, D.A. and Waller, D.M. (2014) Trait-Environment Relationships Remain Strong Despite 50 Years of Trait Compositional Change in Temperate Forests. Ecology, 95, 1780-1791. https://doi.org/10.1890/13-0757.1

[26] Albert, C.H., Thuiller, W., Yoccoz, N.G., Douzet, R., Aubert, S. and Lavorel, S. (2010) A Multi-Trait Approach Reveals the Structure and the Relative Importance of Intra-Vs. Interspecific Variability in Plant Traits. Functional Ecology, 24, 11921201. https://doi.org/10.1111/j.1365-2435.2010.01727.x

[27] Hulshof, C.M., Martínez-Yrízar, A., Burquez, A., Boyle, B. and Enquist, B.J. (2013) Plant Functional Trait Variation in Tropical Dry Forests: A Review and Synthesis. In: Quesada, M., Ed., Tropical Dry Forests in the Americas: Ecology, Conservation, and Management, CRC Press, Boca Raton, 129-140.

https://doi.org/10.1201/b15417-9

[28] Siefert, A., Violle, C., Chalmandrier, L., Albert, C.H., Taudiere, A., Fajardo, A., Aarssen, L.W., Baraloto, C., Carlucci, M.B. and Cianciaruso, M.V. (2015) A Global Meta-Analysis of the Relative Extent of Intraspecific Trait Variation in Plant Communities. Ecology Letters, 18, 1406-1419. https://doi.org/10.1111/ele.12508

[29] Luo, J. and Cardina, J. (2012) Germination Patterns and Implications for Invasiveness in Three Taraxacum (Asteraceae) Species. Weed Research, 52, 112-121. https://doi.org/10.1111/j.1365-3180.2011.00898.x

[30] Gioria, M. and Pyšek, P. (2016) Early Bird Catches the Worm: Germination as a Critical Step in Plant Invasion. Biological Invasions, 1-26. https://doi.org/10.1007/s10530-016-1349-1

[31] Forbis, T.A. (2010) Germination Phenology of Some Great Basin Native Annual Forb Species. Plant Species Biology, 25, 221-230. https://doi.org/10.1111/j.1442-1984.2010.00289.x

[32] Donohue, K., Rubio de Casas, R., Burghardt, L., Kovach, K. and Willis, C.G. (2010) Germination, Postgermination Adaptation, and Species Ecological Ranges. Annual 
Review of Ecology, Evolution, and Systematics, 41, 293-319.

https://doi.org/10.1146/annurev-ecolsys-102209-144715

[33] Goyal, N., Pardha-Saradhi, P. and Sharma, G.P. (2014) Can Adaptive Modulation of Traits to Urban Environments Facilitate Ricinus communis L. Invasiveness? Environmental Monitoring and Assessment, 186, 7941-7948. https://doi.org/10.1007/s10661-014-3978-0

[34] Farahat, E., Galal, T., El-Midany, M. and Hassan, L. (2015) Effect of Urban Habitat Heterogeneity on Functional Traits Plasticity of the Invasive Species Calotropis Procera (Aiton) W.T. Aiton. Rendiconti Lincei, 26, 193-201. https://doi.org/10.1007/s12210-015-0408-3

[35] Moravcová, L., Pyšek, P., Jarošík, V. and Pergl, J. (2015) Getting the Right Traits: Reproductive and Dispersal Characteristics Predict the Invasiveness of Herbaceous Plant Species. PLOS ONE, 10, e0123634. https://doi.org/10.1371/journal.pone.0123634

[36] Deng, X., Ye, W.-H., Feng, H.-L., Yang, Q.-H., Hong-Ling, C., Xu, K.-Y. and Zhang, Y. (2004) Gas Exchange Characteristics of the Invasive Species Mikania Micrantha and Its Indigenous Congener M. Cordata (Asteraceae) in South China. Botanical Bulletin of Academia Sinica, 45, 213-220.

[37] Song, L.-Y., Ni, G.-Y., Chen, B.-M. and Peng, S.-L. (2007) Energetic Cost of Leaf Construction in the Invasive Weed Mikania Micrantha Hbk and Its Co-Occurring Species: Implications for Invasiveness. Botanical Studies, 48, 331-338.

[38] Li, X., Shen, Y., Huang, Q., Fan, Z. and Huang, D. (2013) Regeneration Capacity of Small Clonal Fragments of the Invasive Mikania Micrantha Hbk: Effects of Burial Depth and Stolon Internode Length. PLOS ONE, 8, e84657.

https://doi.org/10.1371/journal.pone.0084657

[39] Tripathi, R., Khan, M. and Yadav, A. (2012) Biology of Mikania Micrantha Hbk: A Review. In: Bhatt, J., Singh, J., Singh, S., Tripathi, R. and Kohli, R., Eds., Invasive Alien Plants: An Ecological Appraisal for the Indian Subcontinent, CAB International, Wallingford, UK, 99-107.

[40] Hong, L., Shen, H., Ye, W., Cao, H. and Wang, Z. (2007) Self-Incompatibility in Mikania Micrantha in South China. Weed Research, 47, 280-283. https://doi.org/10.1111/j.1365-3180.2007.00575.x

[41] Baker, H.G. (1955) Self-Compatibility and Establishment after Long-Distance Dispersal. Evolution, 9, 347-349. https://doi.org/10.2307/2405656

[42] Mal, T.K. and Lovett-Doust, J. (2005) Phenotypic Plasticity in Vegetative and Reproductive Traits in an Invasive Weed, Lythrum Salicaria (Lythraceae), in Response to Soil Moisture. American Journal of Botany, 92, 819-825.

https://doi.org/10.3732/ajb.92.5.819

[43] Pauchard, A., Aguayo, M., Peña, E. and Urrutia, R. (2006) Multiple Effects of Urbanization on the Biodiversity of Developing Countries: The Case of a Fast-Growing Metropolitan Area (Concepción, Chile). Biological Conservation, 127, 272-281. https://doi.org/10.1016/j.biocon.2005.05.015

[44] Dorken, M.E. and Barrett, S.C. (2004) Phenotypic Plasticity of Vegetative and Reproductive Traits in Monoecious and Dioecious Populations of Sagittaria Latifolia (Alismataceae): A Clonal Aquatic Plant. Journal of Ecology, 92, 32-44. https://doi.org/10.1111/j.1365-2745.2004.00857.x

[45] Fridley, J.D., Grime, J.P. and Bilton, M. (2007) Genetic Identity of Interspecific Neighbours Mediates Plant Responses to Competition and Environmental Variation in a Species-Rich Grassland. Journal of Ecology, 95, 908-915.

https://doi.org/10.1111/j.1365-2745.2007.01256.x 
[46] Bates, L., Waldren, R. and Teare, I. (1973) Rapid Determination of Free Proline for Water-Stress Studies. Plant and Soil, 39, 205-207. https://doi.org/10.1007/BF00018060

[47] Zheng, X., Li, X. and Xu, Y. (2007) The Effect of Hydropriming on Germination Barriers of Triploid Watermelon Seeds. In: Adkins, S.W., Ashmore, S. and Navie, S.C., Eds., Seeds. Biology, Development and Ecology, CABI, Egham, 269-278. https://doi.org/10.1079/9781845931971.0269

[48] Lehsten, V. (2005) Functional Analysis and Modelling of Vegetation: Plant Functional Types in a Mesocosmos Experiment and a Mechanistic Model. University of Oldenburg, Oldenburg.

[49] Nelson, D. and Sommers, L. (1973) Determination of Total Nitrogen in Plant Material. Agronomy Journal, 65, 109-112. https://doi.org/10.2134/agronj1973.00021962006500010033x

[50] John, M.K. (1970) Colorimetric Determination of Phosphorus in Soil and Plant Materials with Ascorbic Acid. Soil Science, 109, 214-220. https://doi.org/10.1097/00010694-197004000-00002

[51] Davis, A., Dinan, F., Lobbett, E., Chazin, J. and Tufts, L. (1964) Phosphorus Determination by Flame Photometry. Analytical Chemistry, 36, 1066-1068. https://doi.org/10.1021/ac60212a033

[52] Cleves, M. (2008) An Introduction to Survival Analysis Using Stata. STATA Press, College Station.

[53] Onofri, A., Gresta, F. and Tei, F. (2010) A New Method for the Analysis of Germination and Emergence Data of Weed Species. Weed Research, 50, 187-198. https://doi.org/10.1111/j.1365-3180.2010.00776.x

[54] Subbiah, B. and Asija, G. (1956) A Rapid Procedure for the Estimation of Available Nitrogen in Soils. Current Science, 25, 259-260.

[55] Olsen, S.R. and Sommers, L.E. (1982) Phosphorus. In: Page, A.L., Ed., Methods of Soil Analysis Part 2 Chemical and Microbiological Properties, American Society of Agronomy, Soil Science Society of America, Madison, 403-430.

[56] Chapman, H.D. and Pratt, P.F. (1962) Methods of Analysis for Soils, Plants and Waters. Soil Science, 93, 68. https://doi.org/10.1097/00010694-196201000-00015

[57] Nelson, D.W. and Sommers, L.E. (1982) Total Carbon, Organic Carbon, and Organic Matter. In: Page, A.L., Ed., Methods of Soil Analysis Part 2 Chemical and Microbiological Properties, American Society of Agronomy, Soil Science Society of America, Madison, 539-579.

[58] Lindsay, W.L. and Norvell, W.A. (1978) Development of a Dtpa Soil Test for Zinc, Iron, Manganese, and Copper. Soil Science Society of America Journal, 42, 421-428. https://doi.org/10.2136/sssaj1978.03615995004200030009x

[59] Adamiec, E., Jarosz-Krzemińska, E. and Wieszała, R. (2016) Heavy Metals from Non-Exhaust Vehicle Emissions in Urban and Motorway Road Dusts. Environmental Monitoring and Assessment, 188, 369. https://doi.org/10.1007/s10661-016-5377-1

[60] Anderson, T.-H. (2003) Microbial Eco-Physiological Indicators to Asses Soil Quality. Agriculture, Ecosystems \& Environment, 98, 285-293.

https://doi.org/10.1016/S0167-8809(03)00088-4

[61] Vance, E., Brookes, P. and Jenkinson, D. (1987) An Extraction Method for Measuring Soil Microbial Biomass C. Soil Biology and Biochemistry, 19, 703-707. https://doi.org/10.1016/0038-0717(87)90052-6

[62] Brookes, P.C., Landman, A., Pruden, G. and Jenkinson, D. (1985) Chloroform Fu- 
migation and the Release of Soil Nitrogen: A Rapid Direct Extraction Method to Measure Microbial Biomass Nitrogen in Soil. Soil Biology and Biochemistry, 17, 837-842. https://doi.org/10.1016/0038-0717(85)90144-0

[63] Li, W.-H., Zhang, C.-B., Gao, G.-J., Zan, Q.-J. and Yang, Z.-Y. (2007) Relationship between Mikania Micrantha Invasion and Soil Microbial Biomass, Respiration and Functional Diversity. Plant and Soil, 296, 197-207. https://doi.org/10.1007/s11104-007-9310-9

[64] McNair, J.N., Sunkara, A. and Frobish, D. (2012) How to Analyse Seed Germination Data Using Statistical Time-to-Event Analysis: Non-Parametric and Semi-Parametric Methods. Seed Science Research, 22, 77-95. https://doi.org/10.1017/S0960258511000547

[65] Gunjača, J. and Šarčević, H. (2000) Survival Analysis of the Wheat Germination Data. 22nd International Conference on Information Technology Interfaces, Pula, 13-16 June 2000, 307-310.

[66] Liu, C.-W., Sung, Y., Chen, B.-C. and Lai, H.-Y. (2014) Effects of Nitrogen Fertilizers on the Growth and Nitrate Content of Lettuce (Lactuca Sativa L.). International Journal of Environmental Research and Public Health, 11, 4427-4440. https://doi.org/10.3390/ijerph110404427

[67] Kabata-Pendias, A. (2011) Trace Elements in Soils and Plants. CRC Press, Boca Raton, 201-213.

[68] Tokarz, E. and Urban, D. (2015) Soil Redox Potential and Its Impact on Microorganisms and Plants of Wetlands. Journal of Ecological Engineering, 16, 20-30. https://doi.org/10.12911/22998993/2801

[69] Von der Lippe, M., Bullock, J.M., Kowarik, I., Knopp, T. and Wichmann, M. (2013) Human-Mediated Dispersal of Seeds by the Airflow of Vehicles. PLOS ONE, 8, e52733. https://doi.org/10.1371/journal.pone.0052733

[70] Von der Lippe, M. and Kowarik, I. (2007) Long-Distance Dispersal of Plants by Vehicles as a Driver of Plant Invasions. Conservation Biology, 21, 986-996. https://doi.org/10.1111/j.1523-1739.2007.00722.x

[71] Palacio, S., Milla, R., Albuixech, J., Pérez-Rontomé, C., Camarero, J.J., Maestro, M. and Montserrat-Martí, G. (2008) Seasonal Variability of Dry Matter Content and Its Relationship with Shoot Growth and Nonstructural Carbohydrates. New Phytologist, 180, 133-142. https://doi.org/10.1111/j.1469-8137.2008.02569.x

[72] Rai, P.K. (2016) Biodiversity of Roadside Plants and Their Response to Air Pollution in an Indo-Burma Hotspot Region: Implications for Urban Ecosystem Restoration. Journal of Asia-Pacific Biodiversity, 9, 47-55. https://doi.org/10.1016/j.japb.2015.10.011

[73] Chaturvedi, R., Prasad, S., Rana, S., Obaidullah, S., Pandey, V. and Singh, H. (2013) Effect of Dust Load on the Leaf Attributes of the Tree Species Growing along the Roadside. Environmental Monitoring and Assessment, 185, 383-391. https://doi.org/10.1007/s10661-012-2560-x

[74] Zhang, L., Ye, W., Cao, H. and Feng, H. (2004) Mikania Micrantha Hbk in ChinaAn Overview. Weed Research, 44, 42-49. https://doi.org/10.1111/j.1365-3180.2003.00371.x

[75] Li, W.-H., Zhang, C.-B., Jiang, H.-B., Xin, G.-R. and Yang, Z.-Y. (2006) Changes in Soil Microbial Community Associated with Invasion of the Exotic Weed, Mikania Micrantha Hbk. Plant and Soil, 281, 309-324. https://doi.org/10.1007/s11104-005-9641-3

[76] Swamy, P. and Ramakrishnan, P. (1987) Contribution of Mikania Micrantha during 
Secondary Succession Following Slash-and-Burn Agriculture (Jhum) in North-East India Ii. Nutrient Cycling. Forest Ecology and Management, 22, 239-249. https://doi.org/10.1016/0378-1127(87)90108-3

[77] McAlpine, K.G., Lamoureaux, S.L. and Westbrooke, I. (2015) Ecological Impacts of Ground Cover Weeds in New Zealand Lowland Forests. New Zealand Journal of Ecology, 39, 50.

[78] Hayat, S., Hayat, Q., Alyemeni, M.N., Wani, A.S., Pichtel, J. and Ahmad, A. (2012) Role of Proline under Changing Environments: A Review. Plant Signaling \& Behavior, 7, 1456-1466. https://doi.org/10.4161/psb.21949

[79] Grotkopp, E. and Rejmánek, M. (2007) High Seedling Relative Growth Rate and Specific Leaf Area Are Traits of Invasive Species: Phylogenetically Independent Contrasts of Woody Angiosperms. American Journal of Botany, 94, 526-532. https://doi.org/10.3732/ajb.94.4.526

[80] Reich, P.B., Walters, M.B. and Ellsworth, D.S. (1997) From Tropics to Tundra: Global Convergence in Plant Functioning. Proceedings of the National Academy of Sciences, 94, 13730-13734. https://doi.org/10.1073/pnas.94.25.13730

[81] Wilson, P.J., Thompson, K. and Hodgson, J.G. (1999) Specific Leaf Area and Leaf Dry Matter Content as Alternative Predictors of Plant Strategies. New Phytologist, 143, 155-162. https://doi.org/10.1046/j.1469-8137.1999.00427.x

[82] Dyer, A., Fenech, A. and Rice, K. (2000) Accelerated Seedling Emergence in Interspecific Competitive Neighbourhoods. Ecology Letters, 3, 523-529. https://doi.org/10.1046/j.1461-0248.2000.00187.x

[83] Verdú, M. and Traveset, A. (2005) Early Emergence Enhances Plant Fitness: A Phylogenetically Controlled Meta-Analysis. Ecology, 86, 1385-1394. https://doi.org/10.1890/04-1647

[84] Gioria, M., Pyšek, P. and Osborne, B.A. (2016) Timing Is Everything: Does Early and Late Germination Favor Invasions by Herbaceous Alien Plants? Journal of Plant Ecology, rtw105. https://doi.org/10.1093/jpe/rtw105

[85] Klimkowska, A., Van Diggelen, R., Den Held, S., Brienen, R., Verbeek, S. and Vegelin, K. (2009) Seed Production in Fens and Fen Meadows along a Disturbance Gradient. Applied Vegetation Science, 12, 304-315. https://doi.org/10.1111/j.1654-109X.2009.01024.x

[86] Baker, H.G. (1974) The Evolution of Weeds. Annual Review of Ecology and Systematics, 5, 1-24. https://doi.org/10.1146/annurev.es.05.110174.000245

[87] Feng, Y.-L., Lei, Y.-B., Wang, R.-F., Callaway, R.M., Valiente-Banuet, A., Li, Y.-P. and Zheng, Y.-L. (2009) Evolutionary Tradeoffs for Nitrogen Allocation to Photosynthesis versus Cell Walls in an Invasive Plant. Proceedings of the National Academy of Sciences, 106, 1853-1856. https://doi.org/10.1073/pnas.0808434106

[88] Roy, A. and Singh, K. (2003) Dynamics of Microbial Biomass and Nitrogen Supply During Primary Succession on Blastfurnace Slag Dumps in Dry Tropics. Soil Biology and Biochemistry, 35, 365-372. https://doi.org/10.1016/S0038-0717(02)00286-9

[89] Sparling, G.P. (1992) Ratio of Microbial Biomass Carbon to Soil Organic Carbon as a Sensitive Indicator of Changes in Soil Organic Matter. Soil Research, 30, 195-207. https://doi.org/10.1071/SR9920195

[90] Banerjee, A.K. and Dewanji, A. (2012) Mikania Micrantha Hbk-a Potential and Economical Threat to Global Biodiversity with Special Emphasis on the Indian Context. Proceedings of the 18 th Australasian Weeds Conference Frankston, Melbourne, 8-11 October 2012, 17-20. 
Submit or recommend next manuscript to SCIRP and we will provide best service for you:

Accepting pre-submission inquiries through Email, Facebook, LinkedIn, Twitter, etc. A wide selection of journals (inclusive of 9 subjects, more than 200 journals)

Providing 24-hour high-quality service

User-friendly online submission system

Fair and swift peer-review system

Efficient typesetting and proofreading procedure

Display of the result of downloads and visits, as well as the number of cited articles Maximum dissemination of your research work

Submit your manuscript at: http://papersubmission.scirp.org/

Or contact ajps@scirp.org 